\title{
The Journey from School to Forming a Family
}

\author{
By ANNA-LIISA SYSIHARJU
}

Assistant professor

Joensuu University

Department of Education

Observations in the light of a longitudinal study on the process of gaining adulthood among a group of lower secondary school students with some questions on the interaction between education policy and population policy.

\section{Introduction: research on becoming an adult as a prerequisite to research on the family}

As the different areas of the behavioral and social sciences diverge and become ever more numerous each separate study often concentrates mainly on only one of the many segments belonging to the same social reality. When this happens the research population is defined and limited mainly from this special perspective. Thus educational research is primarily interested in people within the sphere of education and in variables pertaining to educational situations, labour research in people on the labour market and variables pertaining to job situations, population and family policy research in people living in families and family variables, etc.

However, when these separate studies are joined together, the picture of social reality they form is incomplete, unless it is supplemented with broader although perhaps more inexact studies, where information is gathered at the same time from different segments of human life and from the same relatively unselected population. Thus relations between different segments are sought out in a field from which population groups that appear less significant have not been shut out beforehand. Broad-based surveys like this seem especially fruitful as longitudinal studies, where the same people are followed for a long period of time. The relations between different events and different areas of life can be examined from a time perspective and thus, factors pertaining to the formation of different phases of life can be followed in practice.

Here in Finland there have been few of the above-mentioned bridges between population and family research and youth and educational research except in a few general surveys of the youth situation (Aalto \& Minkkinen 1971; Rantalaiho 1968). All the same, the young are an important group from the 
standpoint of a broadly-based family study on two accounts: for one, young people are economically, socially and emotionally tied in many ways to the families of the previous generation, whose situation and life young people for their own part affect. Secondly, these young people will be forming the families of the next generation, so that the situation they are in, their personal decisions and their attitudes will thus be reflected far into the future. Because of the rapid changes toward a more industrialized and urban society both attitudes and the situation families and young people are in are going under great change and pressure, which demands continuous examination of assumptions pertaining to them.

Thus one of the prerequisites of family and population research is research on gaining adulthood, the study of the process during which a young person breaks away both economically and socially from the family of his childhood and possibly starts a new family unit. (The concept of gaining adulthood must naturally not be limited only to family events, instead it should, in principle, be kept separate. However, at this time, society and general opinion consider socio-economic independence and/or one's own family fundamental signs of being an adult.) Knowledge of this process of change is also needed for a foundation on which to develop family education.

\section{Educational research as research on gaining adulthood: The Upper Secondary School Study 1964-71}

As much as education is said to stress preparation for the future, educational research for its part has passed over the actual events in the process by which the young socially gain adulthood. This has been caused in part by the scarcity of longitudinal studies, especially of studies going past the schooling phase in life, and in part by the intense concentration of educational research on the sphere of the school, the scholastic side of schooling and the measurement of its results.

In 1964, in connection with a joint-Nordic project I was given responsibility for the Finnish portion of the so-called Upper Secondary School Study, which would clarify the process of transferring into upper secondary school as a longitudinal study that would follow the same students through upper secondary school (see Sysiharju 1972, Chapter 1). At the same time I wanted to use the opportunity to gather a large body of information, where on the one hand the events in the lives of all the young people belonging to the initial cohorts would be followed continuously, regardless of their position in relation to schooling, and the other hand, as much information as possible other than just that relating directly to schooling would be gathered.

This is how the project called The Upper Secondary School Study 1964-71 began, starting with 1435 young people. These young people made up 38 classroom units in $1964 / 65$ at the highest grade level of lower secondary school 
in different secondary schools in both urban and rural areas, in Helsinki, Southern Häme, Lapland and Northern Carelia. First, a large body of information was gathered on their decision to transfer to upper secondary school and then on their actual transfer. Later they and the events that took place in their lives were followed for the next six school years up till the last postal survey in 1970/71. In the publication "Keskikoulusta eteenpäin 1960-luvun Suomessa. Lukiotutkimus 1964-71: koulutusurat» — "On from lower secondary school in Finland in the 1960's. The Upper Secondary School Study 1964/ 71: schooling channels» (Sysiharju 1972) the study in its entirety is explained in detail, as are the publications written about it earlier and, especially, the schooling channels and other phases that formed during these seven years for the people under study.

Here I will concentrate mainly on presenting the picture that gradually formed, as a by-product of this study on schooling, of the seven-year process of growing up of a group of young people at the turn of the seventies. Gaining adulthood has been defined in this context first as gaining independence and breaking away from the childhood home and secondly as development toward a new family unit. Three different aspects are described:

a) at what stage in the development toward a new family unit were these young people when finishing lower secondary school (15-17 years old)?

b) how much independence from the childhood home had been gained and transfer toward new family units taken place among these same people six years later (average age $21-22$ years)?

c) what connection was there between the schooling choices made by these individuals at the lower secondary school level and the above-mentioned matters, and what effect did the individual's sex have?

\section{The attitudes toward gaining adulthood of those finishing lower secondary school}

The group of 1435 young people chosen at the beginning of the Secondary School Study 1964 - 71 proved to be very representative, in regard to its main characteristics, of the group of young people then finishing lower secondary school. In respect to population research this group represented an interesting generation: those born in 1948 and 1949, which included most of those in the highest grade of lower secondary school in 1964/65, belonged to the so-called large age groups born after the war, where the number of births per year was over 100000 . Ever since their birth these large groups have been in many exceptional positions merely because of their number.

When coming to secondary school age in 1958-60 these age groups experienced a squeeze, in that only $65 \%$ of those trying to get into secondary school could be accepted, even though the number trying to get in was noticeably 
smaller in proportion to the entire age group than later on. In coming to the highest grade of lower secondary school in 1964/65 the number at this level made up $40 \%$ of the 15-year-old age group. Thus the youth cohort studied here does not illustrate all who were the same age at this same time. This was a group that had been narrowed down: a group that had tried to get in, had been accepted and had been able to remain in secondary school until the end of lower secondary school. Either because of external circumstances and/or scholastic success, they were apparently in a somewhat better than average position in their age group- representing, however, already quite a broad front of those the same age.

Fifty-two percent of the original group in the last year of lower secondary school transferred the following fall to upper secondary school and $30 \%$ left school after lower secondary school. The remaining $18 \%$ remained in lower secondary school and repeated the final grade. Two-thirds of these students later left school after lower secondary school and one-third transferred to upper secondary school after this delay.

Why everyone who had come to the end of lower secondary school did not transfer to upper secondary school turned out to be a more interesting question in The Upper Secondary School Study 1964/71 than why some did transfer especially when it turned out that for most the decision not to transfer was voluntary and reasoned out and not merely a decision forced by external circumstances or a negative reflection of transfering to lukio. Efforts to gain adulthood which the investigator had included only as a minor factor in a broad view, proved here to be a much more significant instigator than expected.

In regard to the person most influencing the decision concerning schooling the group going on to upper secondary school and the group leaving after lower secondary school did not differ significantly from each other, although members of the family seemed slightly more often to have influenced a decision to transfer into upper secondary school than a decision to stay out. The person's own wishes in either direction had clearly been realized more often than the wishes of the parents. Leaving school after lower secondary school occurred less frequently against the person's own wishes than did going on to upper secondary school and again going on to upper secondary school occurred less frequently against the parents' wishes than did leaving after lower secondary school. Thus the Finnish family let the young person himself have the most say in the decision concerning upper secondary school.

Factors measuring the urgency of efforts to gain adulthood and independence rose above all others in significance, when comparing those who transferred into upper secondary school and those who left school. The apparent majority of the former were ready to postpone gaining adulthood, the equally apparent majority of the latter no longer wanted to wait for their independence. The groups differed in these respects, as they did in enjoying school, even more strongly than they differed in regard to previous scholastic achievement or the occupational group of the parents or guardian (Sysiharju 1972, Chapter 
VI). In all of these subgroups there were both those who were drawn away from secondary school by more urgent efforts to gain adulthood and those whose transfer to upper secondary school related to a willingness to wait yet for greater external independence and a desire to postpone decisions for a while yet.

Well over one-half of the mainly 14-16-year-old students finishing lower secondary school reported that their closest circle of friends included members of both sexes, and also over one-half reported having a close friend of the opposite sex. It is probably a reflection of sex-roles that while boys and girls did not differ in this latter respect, boys reported slightly more often than girls that their regular circle of friends included members of their own sex only.

The friends of the majority were secondary school students - although not necessarily from their own class - but for at least one out of five students friends came mainly from outside secondary school. Girlfriends (of both girls and boys) were more often secondary school students than were boyfriends, but one girl out of three had a close boyfriend outside of secondary school. About every other girl also had a boyfriend older than herself, but the girlfriends of boys were very rarely older.

Most of the features of these friendships caused statistically significant differences between those who transferred to upper secondary school and those who left after lower secondary school, although these differences were not very large. Those who left after lower secondary school were already at that time more frequently seeing members of the opposite sex in both their group of friends and in close friendships, and more often their friends came from outside secondary school. Girls who left after lower secondary school had a boyfriend outside of secondary school more often than did girls who transferred to upper secondary school and more often he was older.

In comparing those who went on to upper secondary school and those who left after lower secondary school it was shown that they did not differ at all in the choice of value goals: out of eight alternatives the goals thought most important by both groups were, with almost exactly the same rating, a secure income, enjoying life and leisure, and developing oneself. Thus differences between these groups were not associated with differences concerning goals. The majority of both those going into upper secondary school and those staying out were striving for the same goals, mainly those assuring them security and happiness, but each group saw a different path leading to these goals.

In regard to the picture they had of what their own life would be like in 15 years those who went to upper secondary school and those who left school did not differ very much from each other. In both groups the majority imagined that they would be living in the city. However, there was a minority in both groups considering living in the country as well as a small group thinking about settling abroad. In both groups one-family houses and row houses were equally as often chosen as ideal homes.

The attitude toward whether the wife should work outside the home or not 
smaller in proportion to the entire age group than later on. In coming to the highest grade of lower secondary school in 1964/65 the number at this level made up $40 \%$ of the 15 -year-old age group. Thus the youth cohort studied here does not illustrate all who were the same age at this same time. This was a group that had been narrowed down: a group that had tried to get in, had been accepted and had been able to remain in secondary school until the end of lower secondary school. Either because of external circumstances and/or scholastic success, they were apparently in a somewhat better than average position in their age group- representing, however, already quite a broad front of those the same age.

Fifty-two percent of the original group in the last year of lower secondary school transferred the following fall to upper secondary school and $30 \%$ left school after lower secondary school. The remaining $18 \%$ remained in lower secondary school and repeated the final grade. Two-thirds of these students later left school after lower secondary school and one-third transferred to upper secondary school after this delay.

Why everyone who had come to the end of lower secondary school did not transfer to upper secondary school turned out to be a more interesting question in The Upper Secondary School Study 1964/71 than why some did transfer especially when it turned out that for most the decision not to transfer was voluntary and reasoned out and not merely a decision forced by external circumstances or a negative reflection of transfering to lukio. Efforts to gain adulthood which the investigator had included only as a minor factor in a broad view, proved here to be a much more significant instigator than expected.

In regard to the person most influencing the decision concerning schooling the group going on to upper secondary school and the group leaving after lower secondary school did not differ significantly from each other, although members of the family seemed slightly more often to have influenced a decision to transfer into upper secondary school than a decision to stay out. The person's own wishes in either direction had clearly been realized more often than the wishes of the parents. Leaving school after lower secondary school occurred less frequently against the person's own wishes than did going on to upper secondary school and again going on to upper secondary school occurred less frequently against the parents' wishes than did leaving after lower secondary school. Thus the Finnish family let the young person himself have the most say in the decision concerning upper secondary school.

Factors measuring the urgency of efforts to gain adulthood and independence rose above all others in significance, when comparing those who transferred into upper secondary school and those who left school. The apparent majority of the former were ready to postpone gaining adulthood, the equally apparent majority of the latter no longer wanted to wait for their independence. The groups differed in these respects, as they did in enjoying school, even more strongly than they differed in regard to previous scholastic achievement or the occupational group of the parents or guardian (Sysiharju 1972, Chapter 
VI). In all of these subgroups there were both those who were drawn away from secondary school by more urgent efforts to gain adulthood and those whose transfer to upper secondary school related to a willingness to wait yet for greater external independence and a desire to postpone decisions for a while yet.

Well over one-half of the mainly 14-16-year-old students finishing lower secondary school reported that their closest circle of friends included members of both sexes, and also over one-half reported having a close friend of the opposite sex. It is probably a reflection of sex-roles that while boys and girls did not differ in this latter respect, boys reported slightly more often than girls that their regular circle of friends included members of their own sex only.

The friends of the majority were secondary school students - although not necessarily from their own class - but for at least one out of five students friends came mainly from outside secondary school. Girlfriends (of both girls and boys) were more often secondary school students than were boyfriends, but one girl out of three had a close boyfriend outside of secondary school. About every other girl also had a boyfriend older than herself, but the girlfriends of boys were very rarely older.

Most of the features of these friendships caused statistically significant differences between those who transferred to upper secondary school and those who left after lower secondary school, although these differences were not very large. Those who left after lower secondary school were already at that time more frequently seeing members of the opposite sex in both their group of friends and in close friendships, and more often their friends came from outside secondary school. Girls who left after lower secondary school had a boyfriend outside of secondary school more often than did girls who transferred to upper secondary school and more often he was older.

In comparing those who went on to upper secondary school and those who left after lower secondary school it was shown that they did not differ at all in the choice of value goals: out of eight alternatives the goals thought most important by both groups were, with almost exactly the same rating, a secure income, enjoying life and leisure, and developing oneself. Thus differences between these groups were not associated with differences concerning goals. The majority of both those going into upper secondary school and those staying out were striving for the same goals, mainly those assuring them security and happiness, but each group saw a different path leading to these goals.

In regard to the picture they had of what their own life would be like in 15 years those who went to upper secondary school and those who left school did not differ very much from each other. In both groups the majority imagined that they would be living in the city. However, there was a minority in both groups considering living in the country as well as a small group thinking about settling abroad. In both groups one-family houses and row houses were equally as often chosen as ideal homes.

The attitude toward whether the wife should work outside the home or not 
was the same among both those who went on to upper secondary school and those who left school. A small minority felt that continuous contact with one's occupation was necessary (girls thought so twice as often as boys). Another minority twice as large felt that the wife should be constantly at home (boys said this three times as often as girls). Over one-fourth of each group wanted the wife to be at home while the children were small (girls twice as often as boys). Most often in both groups people were willing to let this matter be decided according to the circumstances involved.

All this points to the fact that among people making different decisions concerning education general attitudes were similar in content - differences were caused by timing and rhythm. When the 14-16-year-old students finishing lower secondary school were asked to estimate at what age they thought they would get married, slightly less than one-third guessed this would happen by the age of 22 (girls twice as often as boys). On the other hand almost one out of five felt they would postpone marriage until after they were 25 years old (boys $1^{1 / 2}$ times as often as girls). In these estimates those going on to upper secondary school differed significantly from those leaving after lower secondary school by scheduling adulthood in the form of marriage for later: while $23 \%$ of those going into upper secondary school thought they would get married by the age of $22,40 \%$ of those leaving school made the same estimate, and while two-thirds of those going into upper secondary school estimated their age at marriage at over 23 , only less than half of those leaving school felt this late a marriage would be probable. On the other hand the groups did not differ at all from each other in regard to the one-tenth in each group that doubted they would get married at all.

A faster schedule of gaining adulthood as well as more frequently seeing and dating the opposite sex, a predictor of adulthood, proved to be very important factors, relatively independent from other factors, even from scholastic achievement or social group, in deciding whether one would go on to upper secondary school.

\section{The same group of young people six years later: breaking away from the childhood home and the formation of families by the new generation}

Broader information on the phases and developmental process of youth can be found only after following the same group of individuals over a longer period of time. In the upper secondary school study the last postal questionnaire (for the present) was sent to all those in the original group six school years after they had been in the last year of lower secondary school, in 1970/71, when almost everyone, both those who left after lower secondary school and those who went on to upper secondary school, had already left secondary school (18 \% of those who went on to upper secondary school broke off their studies 
Table 1. The practical and economic independence achieved by the year $1970 / 71$ by students who had been in the highest grade of lower secondary school together in 1964/65: everyone, both boys and girls who went through upper secondary school and boys and girls who left school after lower secondary school.*

Housing, education, income and work
Those who finished upper secondary

$\frac{\text { school }}{\text { Total Boys Girls }}$

Total

(1071)

$\%$

$\begin{array}{ccc}(569) & (243) & (326) \\ \% & \% & \%\end{array}$

Those who left after lower secondary

\begin{tabular}{ccc}
\multicolumn{3}{c}{ school } \\
\hline Total & Boys & Girls \\
$(399)$ & $(163)$ & $(236)$ \\
$\%$ & $\%$ & $\%$
\end{tabular}

\section{Housing}

permanent residence

- with spouse

— with friend

- alone

not with parents, total with parents

\begin{tabular}{rrrrrrr}
19 & 9 & 6 & 11 & 32 & 25 & 38 \\
9 & 10 & 8 & 11 & 7 & 7 & 7 \\
8 & 6 & 5 & 7 & 11 & 8 & 13 \\
\hline 36 & 25 & 19 & 29 & 50 & 40 & 58 \\
59 & 69 & 76 & 65 & 43 & 55 & 35
\end{tabular}

temporary residence in addition to permanent residence

permanent residence only

$\begin{array}{lllllll}39 & 52 & 56 & 49 & 21 & 28 & 17\end{array}$

\section{Education}

being educated right now:

- in university or college

60

47

50

$\begin{array}{lll}77 & 69 & 82\end{array}$

- in vocational school

$\begin{array}{rrrrrrr}44 & 66 & 60 & 69 & 18 & 32 & 7 \\ 23 & 45 & 48 & 42 & - & - & - \\ 21 & 21 & 12 & 27 & 18 & 32 & 7\end{array}$

been previously in a vocational school at least 1 semester at least 1 year at least 2 years at least 3 years

$\begin{array}{rrrrrrr}47 & 30 & 14 & 41 & 66 & 65 & 67 \\ 38 & 18 & 7 & 27 & 59 & 62 & 58 \\ 22 & 15 & 2 & 8 & 40 & 43 & 39 \\ 6 & 0 & 0 & 0 & 13 & 15 & 11\end{array}$

Main income

\begin{tabular}{|c|c|c|c|c|c|c|c|}
\hline own job - continuous & 36 & 17 & 16 & 17 & 59 & 60 & 58 \\
\hline own job - during vacation & 4 & 5 & 6 & 4 & 3 & 3 & 3 \\
\hline spouse's job & 10 & 4 & 1 & 7 & 18 & 5 & 26 \\
\hline $\begin{array}{l}\text { economically independent, } \\
\text { total }\end{array}$ & 50 & 26 & 23 & 28 & 80 & 68 & 87 \\
\hline student loan, stipend, etc. & 34 & 50 & 50 & 51 & 14 & 24 & 6 \\
\hline from parents & 16 & 22 & 24 & 20 & 7 & 8 & 6 \\
\hline $\begin{array}{l}\text { Work } \\
\text { working at the moment: } \\
\text { - percentage of these with }\end{array}$ & 41 & 19 & 20 & 19 & 69 & 59 & 76 \\
\hline a permanent job & 30 & 7 & 5 & 9 & 60 & 50 & 67 \\
\hline
\end{tabular}

* Sysiharju 1972, Chapter IX. The questionnaire was answered by $80 \%$ of the original sample, this comparison does not include those who started but did not complete upper secondary school. 
in upper secondary school, $44 \%$ passed their matriculation examination in the usual three years, $29 \%$ with a one year's delay, $7 \%$ with a two year's delay and the final $2 \%$ were still in upper secondary school six school years later). This postal questionnaire 1970/71 mainly concerned how those in the study were settled at the time in a job or in schooling, and their personal and family situation. Success in contacting the people and having them answer the questionnaire was quite good in respect to the long time span involved and high mobility. Altogether $80 \%$ of those originally studied answered the questionnaire.

Next we shall examine the adulthood of these young people, especially their independence and the formation of new families, six years later or mainly at $20-22$ years of age. We shall compare how these actual features of adulthood are connected with decisions concerning education made earlier at the end of lower secondary school. Those people who originally sat in the same class are being compared, some of whom later decided to leave school right after lower secondary school, and others who went all the way through upper secondary school and passed their matriculation examination. Both groups include a small number of people who repeated the final grade of lower secondary school first.

\subsection{Housing}

A large number, about two-fifths of the young people, had a temporary residence in some other locality in addition to a permanent residence, usually because they were studying there. In regard to the general need for housing the number living in two places is considerable. A better indication of independence, however, is that the person's permanent residence was also no longer with his parents, the original family.

The decision concerning further education made after lower secondary school was clearly connected with how housing was arranged six years later: at least every other person who had completed upper secondary school had a temporary residence in addition to a permanent home. Only every fifth person who had left after lower secondary school needed a temporary residence at this stage. Indeed, over one-half of those who left after lower secondary school had already gained independence from their family in regard to housing while only one-fourth of those who had completed upper secondary school had done so. The difference was caused above all by the fact that already one-third, or three times as many as among those who had completed upper secondary school, were living with their spouse, and even the number living alone, not with their parents, was almost twice the number living alone who had completed upper secondary school.

At the lower secondary school level boys and girls differed noticeably from each other in very few respects. In particular, their decisions concerning educa- 
tion did not differ significantly, although a slightly smaller number of girls than boys did not go on to upper secondary school. Six years later the differences between the sexes were clearly greater than before in the two groups making different decisions about education - however, these differences were smaller than the differences regarding the decision about education itself. It is perhaps surprising that in both education group there were more girls than boys who had already moved permanently away from home. This difference is caused not only by those living with their spouse: in both groups the number of girls living independently with a friend or alone was also greater than the number of boys.

\subsection{Education}

Both current education and previous education were distributed quite differently among former classmates according to the choice about education made at the lower secondary school phase. The majority, two-thirds, of those who had finished upper secondary school were still currently being educated. However, less than one out of two students who had passed the matriculation examination was attending a university and every fifth student was currently in some sort of vocational school. On the other hand only a minority, less than one-third, had already been in a vocational school for even one semester, and for example only $15 \%$ of the students who had passed their matriculation examination had had at least two years of vocational training.

Then again at the time of the questionnaire only a small minority, less than one-fifth, of the group who had left after lower secondary school was still being trained in a vocational school, but the majority of the group, twothirds, had already had at least one semester of vocational school. Altogether $40 \%$ of them had been in a vocational school for at least two years and well over one-tenth had studied for three years. Thus the phase of all-day vocational training was starting to be over for those who had left after lower secondary school, and for most it was already over.

Variation in education according to sex was different among those classmates who went through upper secondary school and those who left school after the final grade of lower secondary school. In the latter group where people had more frequently already finished their further training, both boys and girls had just about as often attended at least one semester of a vocational school, but longer periods of vocational training seemed to have been slightly more frequent among boys than girls, although the difference was not significant. At the time of the questionnaire on the other hand, the number of boys who had left school after lower secondary school and who were still receiving their vocational training was clearly greater than the number of girls - which thus will finally increase the frequency of longer vocational training among the boys. 
Among the group who had gone through upper secondary school girls had already attended a vocational school for at least one semester much more often than boys and more girls than boys were also attending one at the time of the questionnaire. However, in this group a somewhat larger number of boys than girls were studying at a university. As a final result then we find that also among those who attended upper secondary school boys have a longer period of further education than do girls. (When comparing boys and girls in groups making different choices concerning education, it must be taken into consideration that $80 \%$ of the boys who had left after lower secondary school had already completed their military training some time during these six years, while only $20 \%$ of their classmates who had gone on to upper secondary school had done so - which is also another difference between these groups in the degree of adulthood.)

\subsection{Work and income}

In regard to their main source of income and work the group had gained adulthood relatively slowly in six years. Those whose main source of income came from wages made up only one-half of the whole group, and this figure also included those who lived on their spouse's wages, not their own. At the time of the questionnaire four out of ten of those originally studied were working, but only three out of ten said they considered this job permanent. However, parents were still the major source of income for only a small number. Twice this amount said their main source of income was a student loan, stipend, etc, in a way an advance on the cost of living paid to the student by society.

According to the decision concerning education made earlier, income and work was distributed even more differently than was further education: only a minority, one out of four of those who had attended upper secondary school were economically independent, living on their wages, and less than every tenth person considered their current job permanent. Again a large majority, four out of five, of those who had left after lower secondary school already received wages as their main source of income. The majority, three out of five, also considered their current job permanent and only under one-tenth still received their main income from their parents.

In both school groups girls had become more economically independent than boys. However, girls more often than boys (note however that it did occur among boys) depended on their spouse's wages for economic independence from their parents, but there was also a larger number of girls with a permanent job than there were boys. This difference was especially apparent among those who had left after lower secondary school.

Thus Table 1 shows that becoming an adult as measured by living permanently apart from the parents, no longer being educated, being economically 
independent and having a permanent job had at most reached the half-way mark among the entire group of former classmates six years after they had finished lower secondary school. The majority of those who had left after lower secondary school had socially already gained adulthood, while only a minority of those who completed upper secondary school had done so. In both groups there were somewhat more girls than boys who had gained adulthood early.

The more frequent evidence of adulthood among those who left after lower secondary school, especially as seen in leaving the home of the parents, is also reflected in a higher frequency of leaving the commune where they lived than among those who went on to upper secondary school. - This difference was especially apparent among those who had originally lived in a rural commune. In all groups girls had moved to a different commune or abroad more often than boys.

\subsection{Marriage and marriage plans}

As shown above some of the people in the study had already married during the six years since lower secondary school. Table 2 shows the stages of the marriage process in more detail according to the postal survey 1970/71.

Slightly more than one out of five people who were in the last grade of lower secondary school at the same time were married six years later, when most of the group were $20-22$ years old. A majority of those who were single were dating steadily. The responses showed, without it having to be asked, that some of these dating relations meant the couple was living together.

The questionnaire also inquired about dating relationships and marriage plans. Two-thirds of those who were dating steadily were not considering marriage in the near future, while only one-third thought they would get married that year or the next. On the other hand almost one-third of those who were not dating steadily still felt that marriage would be very possible sometime in the next few years. - On the other hand an equal number, every tenth person answering the questionnaire, were not sure they would ever get married. Marriage in other words did not seem any more a necessary part of their future now than at the lower secondary school phase. On the basis of the responses it can be estimated that in the next few years, when most of these people are $22-24$ years old, almost half of the original group would be married.

The process of entering marriage also differed among those who had made different choices concerning further education: only one out of ten people who had completed upper secondary school was married six years after lower secondary school, but four times as many of their classmates who had left after lower secondary school were married. For the latter group this was well in accordance with the estimates they themselves had made at the lower secondary 
Table 2. The marriages and marriage plans in 1970/71 of people who had been in the final grade of lower secondary school together in 1964/65: Everyone, boys and girls who went through upper secondary school and boys and girls who left after lower secondary school.*

\begin{tabular}{|c|c|c|c|c|c|c|c|}
\hline & \multirow[b]{2}{*}{$\begin{array}{c}\text { Total } \\
(1084) \\
\%\end{array}$} & \multicolumn{3}{|c|}{$\begin{array}{l}\text { Those who completed } \\
\text { upper secondary } \\
\text { school }\end{array}$} & \multicolumn{3}{|c|}{$\begin{array}{c}\text { Those who left after } \\
\text { lower secondary } \\
\text { school }\end{array}$} \\
\hline & & $\begin{array}{c}\text { Total } \\
(567) \\
\%\end{array}$ & $\begin{array}{c}\text { Boys } \\
(242) \\
\%\end{array}$ & $\begin{array}{c}\text { Girls } \\
(325) \\
\%\end{array}$ & $\begin{array}{c}\text { Total } \\
(414) \\
\%\end{array}$ & $\begin{array}{c}\text { Boys } \\
(167) \\
\%\end{array}$ & $\begin{array}{c}\text { Girls } \\
(247) \\
\%\end{array}$ \\
\hline \multicolumn{8}{|l|}{ Main groups } \\
\hline married & 22 & 10 & 6 & 13 & 38 & 31 & 43 \\
\hline dating steadily & 41 & 46 & 46 & 46 & 35 & 37 & 31 \\
\hline \multirow[t]{2}{*}{ not dating } & 37 & 44 & 48 & 41 & 29 & 32 & 26 \\
\hline & 100 & 100 & 100 & 100 & 100 & 100 & 100 \\
\hline Sub-groups & & & & & & & \\
\hline $\begin{array}{l}\text { married } \\
\text { dating steadily } \\
\text { - marriage this year or }\end{array}$ & 22 & 10 & 6 & 13 & 38 & 31 & 43 \\
\hline $\begin{array}{l}\text { next year } \\
\text { - no marriage in the }\end{array}$ & 13 & 12 & 9 & 15 & 12 & 12 & 12 \\
\hline $\begin{array}{l}\text { near future } \\
\text { not dating }- \text { marriage }\end{array}$ & 28 & 34 & 37 & 31 & 22 & 25 & 19 \\
\hline $\begin{array}{l}\text { possible however in } \\
\text { the next few years }\end{array}$ & 10 & 11 & 11 & 11 & 8 & 8 & 8 \\
\hline not dating - marriage & & & & & & & \\
\hline definitely later & 15 & 19 & 26 & 13 & 11 & 18 & 10 \\
\hline $\begin{array}{l}\text { not sure if marriage } \\
\text { ever likely }\end{array}$ & & & & & 7 & 5 & 8 \\
\hline \multirow{2}{*}{ no answer } & $\begin{array}{r}10 \\
2\end{array}$ & $\begin{array}{r}12 \\
2\end{array}$ & 2 & $\begin{array}{r}15 \\
2\end{array}$ & 2 & 2 & $\begin{array}{l}0 \\
2\end{array}$ \\
\hline & 100 & 100 & 100 & 100 & 100 & 100 & 100 \\
\hline $\begin{array}{l}\text { Combination } \\
\text { married now } \\
\text { marriage possible in the }\end{array}$ & 22 & 10 & 6 & 13 & 38 & 31 & 43 \\
\hline next few years & 23 & 23 & 20 & 26 & 20 & 20 & 20 \\
\hline total possibly married soon & 45 & 33 & 26 & 39 & 58 & 51 & 63 \\
\hline
\end{tabular}

* Sysiharju 1972, Chapter IX. This comparison does not include those who started but did not complete upper secondary school.

school level about their marriage rhythm. The marriage process of those who went to upper secondary school seems to have taken place even more slowly then they had estimated beforehand. The majority of those who left after lower secondary school would be married in the next few years.

The differences between the groups educated differently seem to even out because in both groups there was the same number of people dating steadily 
for whom marriage would soon be likely and because there was even a larger number among those who had been to upper secondary school who were not thinking of getting married in the next few years but were still dating steadily than there was among those who left school. On the other hand there were more of all the non-dating sub-groups among those who had completed upper secondary school. There were especially more of those who doubted marriage for themselves entirely. This difference between the two groups had not been visible at the lower secondary school level.

Differences between boys and girls were again similar in both school groups. Considerably more girls were married. Almost every other girl who had left after lower secondary school was married. However, in both school groups boys more often put off marriage into the future, whether they were dating steadily or not. Girls again had more doubts than boys about whether they would ever get married. On the other hand there were more girls than boys among those who had completed upper secondary school who were dating steadily and planning to get married in the next few years.

Altogether it seemed probable that in the next couple of years, at $22-24$ years of age, a majority or two-thirds of the girls who had left after lower secondary school and two-fifths, almost one-half, of the girls who had completed upper secondary school would be married. Soon almost every other boy who had left school after lower secondary school would be married. Only among the boys who had completed upper secondary school was the majority, threefourths, ready to put off marriage until after this period.

\subsection{Early marriages}

The postal survey made six years after lower secondary school also gave some information on the background of the earliest marriages in this group, shown in Table 3. At this point it cannot yet be clarified as to how these marriages and the marriages taking place later in this same group of young people possibly differ from each other. However is important to know what these marriages are like - the first two-fifths of those who left after lower secondary school and the first tenth of those who completed upper secondary school. (Note that the percentages concern only those who were married, and not the entire group under study).

Early marriages clearly clustered around the fifth and sixth year after finishing lower secondary school. However a few people, both boys and girls who had left after lower secondary school had already got married one or two years after lower secondary school, and in this school group one-third of the early marriages had already begun by the end of the fourth year. The early marriages of the girls in both school groups, especially in the group that left after lower secondary school, definitely took place earlier than the early marriages of the boys. 
In one out of three marriages the couple had become acquainted only a short time, at most one year, before getting married. Usually the spouses had known each other for three years at most. In one-fourth of the early marriages the couple had known each other for at least four years. An interesting phenomenon is that people who left after lower secondary school, among whom early marriages were more common and earlier than among those who completed upper secondary school, got married more frequently after a shorter acquaintance. In both groups boys less frequently got married early. However, those who did get married early did so on the basis of a shorter acquaintance. Thus one extreme group was formed by the boys who had left after lower secondary school and where early marriage was based for almost every second boy on at most a one year's acquaintance and for less than one-fifth on at least a four year's acquaintance. The other extreme group was girls who had completed upper secondary school, where only one out of five girls had based her early marriage on at most a one year's acquaintance and almost two out of five had a background of at least a four year's acquaintance with the spouse.

In early marriages the age of the spouse was not often very near the age of the person in question. While the people in the original group were usually born in 1948-50, in two out of three early marriages the spouse was born earlier, and in every tenth case much earlier. However only the girls, and especially those who left after lower secondary school, had married early with a person several years older than themselves. Only one out of five of the girls' early marriages had taken place with someone from the same age group or slightly younger. Thus a husband of the same age seemed to be the exception in the early marriages of the girls and one at least a few years older the rule.

The spouse in these early marriages did not always have the same educational background as the person from the original sample. Almost every other spouse had an elementary school background. There were a few who had completed lower secondary school. At the lower secondary school level the apparent majority of the investigated group had had in their closest circle of friends people who attended lower secondary school and their closest friends of both the same and the opposite sex also in most cases attended secondary school. Nevertheless the spouses in these early marriages had often been found from among those who had had less basic education.

More of the spouses in the early marriages of those who had left after lower secondary school had not graduated from lower secondary school than in the group which had completed upper secondary school (where they numbered one in four). In both school groups more of the girls' husbands than the boys' wives had only an elementary school education. In two-thirds of the early marriages of the girls who had left after lower secondary school (already $43 \%$ of these girls) the husband had not completed lower secondary school and only one husband in ten had completed upper secondary school. In the small number of early marriages entered by boys who had completed upper secondary school only one wife had only an elementary school education and two-thirds had com- 
$\mathrm{Table} 3$. Information on the background, choice of spouse and children of the early marriages (entered by 1970/71) of those who were in the final grade of lower secondary school together in 1964/65: The entire married group, both married boys and girls who had completed upper secondary school by 1968 and 1969 and married boys and girls who had left school after lower secondary school.*

Information on marriages 1970/71
Those who completed upper secondary

\begin{tabular}{cccc} 
& \multicolumn{3}{c}{ school } \\
\cline { 2 - 4 } Total & Total & Boys & Girls \\
$(243)$ & $(54)$ & $(14)$ & $(40)$ \\
$\%$ & $\%$ & $\%$ & $\%$
\end{tabular}

Those who left after lower secondary school

Total Boys Girls

(158) (50) (108)

Year of marriage:

1965-66 (1st-2nd year)

1967-68 (3rd-4th year)

\begin{tabular}{rrrrrrr}
4 & 0 & 0 & 0 & 6 & 2 & 7 \\
25 & 9 & 7 & 10 & 31 & 24 & 34 \\
71 & 91 & 93 & 90 & 63 & 74 & 59 \\
\hline 100 & 100 & 100 & 100 & 100 & 100 & 100
\end{tabular}

Length of acquaintance

before marriage:

1 year

\begin{tabular}{rrrrrrr}
32 & 24 & 29 & 22 & 34 & 43 & 30 \\
42 & 44 & 50 & 43 & 42 & 39 & 44 \\
19 & 26 & 14 & 30 & 16 & 12 & 18 \\
7 & 6 & 7 & 5 & 8 & 6 & 8 \\
\hline 100 & 100 & 100 & 100 & 100 & 100 & 100
\end{tabular}

$2-3$ years

4-5 years

over 5 years

Year of spouse's birth

\begin{tabular}{rrrrrrrr}
$1933-37$ & 1 & 2 & 0 & 2 & 1 & 0 & 1 \\
$1938-42$ & 10 & 4 & 0 & 5 & 12 & 0 & 17 \\
$1943-47$ & 54 & 59 & 29 & 71 & 53 & 32 & 62 \\
$1948-53$ & 35 & 35 & 71 & 22 & 25 & 68 & 20 \\
\cline { 2 - 8 } & 100 & 100 & 100 & 100 & 100 & 100 & 100
\end{tabular}

Basic education of spouse:

elementary school

$\begin{array}{lllllll}46 & 20 & 7 & 25 & 54 & 42 & 60\end{array}$

part of lower secondary school

lower secondary school

part of upper secondary school

upper secondary school

Foreign-born spouse:

$\begin{array}{rrrrrrr}5 & 4 & 0 & 5 & 6 & 8 & 5 \\ 20 & 17 & 21 & 15 & 21 & 24 & 19\end{array}$

Families with children:

one child

two children

families with children, total

wife pregnant

\begin{tabular}{rrrrrrr}
5 & 6 & 7 & 5 & 5 & 6 & 11 \\
24 & 53 & 65 & 50 & 14 & 20 & 11 \\
\hline 100 & 100 & 100 & 100 & 100 & 100 & 100 \\
7 & 9 & $\ldots$ & $\ldots$ & 7 & $\ldots$ & $\ldots$
\end{tabular}

\begin{tabular}{rrrrrrr}
36 & 29 & 43 & 24 & 36 & 36 & 36 \\
4 & 4 & 0 & 5 & 4 & 2 & 5 \\
\hline
\end{tabular}

\begin{tabular}{rrrrrrr}
40 & 33 & 43 & 29 & 40 & 38 & 41 \\
16 & 9 & 7 & 10 & 18 & 16 & 18 \\
\hline
\end{tabular}

* Sysiharju 1972, Chapter IX. This comparison does not include those who had started but did not finish upper secondary school. 
pleted upper secondary school. It was already apparent at the lower secondary school level that those choosing upper secondary school and among them especially the boys were more strongly limited to people from secondary school as their dating partners.

There were very few early marriages with foreigners, but their relative number was not so low, in fact they made up every fifteenth marriage. It also seems apparent that those who completed upper secondary school contract such marriages perhaps slightly more often than do those who left after lower secondary school, although according to table 5 the latter group slightly more frequently moved abroad. All available information points also to the fact that girls married foreigners more often than did boys - just as girls also moved abroad more frequently.

At the time of the postal survey about two-fifths of the couples who had married early had children, usually only one child. Since almost three-fourths of the marriages had been contracted either the year of the survey or the year before, the relatively small number of children is understandable. In young marriages the birth of a child is probably often put off till later, unles the marriage was originally contracted because a baby was on the way.

Generally speaking the same differences between the groups in their timetable of gaining adulthood which were noted earlier were repeated in regard to children. More people who had left after lower secondary school and married early had children than did people who had completed upper secondary school and girls from the original group more often than boys. An exception was the small group of married boys who had completed upper secondary school: they had relatively more children than any other group. Perhaps it was these people who usually got married because a baby was expected, for otherwise this sub-group had the slowest marriage rhythm.

While about one in ten of all the former classmates already had or was about to have a child six years after finishing lower secondary school, this figure was only $3-4 \%$ among both boys and girls who had gone to upper secondary school. Every fifth person who left after lower secondary school already had a child: among the girls the figure was well over one-fifth, but among the boys it was slightly lower. In any case the process of becoming an adult was continually progressing in this regard also.

\section{The timing of becoming an adult by leaving the childhood home and forming a new family}

The descriptions presented above of the same group of young people in two different phases of life are meaningful in that they concern people who for a long time were at the same formal starting point and in the same school situations together. They also concern development where the time-order of opinions, attitudes and actual events can be specified at great length. 
As a summary of the features of the process of gaining adulthood described above it can be said that

- at the end of lower secondary school, usually at the age of $14-16$, pressure toward becoming an adult was already apparent in both efforts to gain independence from the childhood family and the guardianship of parents and in development toward the formation of a new family by forming dating relations and estimating an early marrying age;

- six years later, at 20-22 years of age, people actually had both gained independence (received income from work, had taken permanent jobs, no longer lived in the childhood home, had moved to another commune) and formed new families (marital unions had already been formed or were soon to be formed, children had already been born or were soon to be born);

- in both phases individuals differed considerably in their rhythm of becoming an adult: at the lower secondary school phase some felt that rapid independence was important, while others were willing to postpone it, some were dating and seeing the opposite sex in both their broader circle of friends as well as in their close friendship ties, others again kept mainly to their own sex, some estimated that they would get married by the time they were 20 or 22 , while others estimated that marriage would never be opportune or not until the age of 25 etc. Six years later some had already been married for four even five years and even had two children, had gained economic independence, taken a permanent job and moved out of the childhood home, often to another commune. At the same time, however, some of their former classmates were only at the beginning of their vocational training, were not economically independent, still considered the childhood home their permanent residence and postponed marriage for a considerable time. These differences apparent in the rhythm of gaining adulthood are definitely greater then the age differences within the groups and partially independent from these age differences;

- the choice made at the final phase of lower secondary school between whether to leave secondary school or go on to upper secondary school are associated much more strongly than expected with the faster or slower rhythm of efforts to become an adult. This association was independent of such factors as abilities, school achievement, or the social background of the childhood home. Six years later these same groups clearly differed from each other in regard to the actual rapid or slow gaining of adulthood that had taken place. Their efforts had been realized.

- in both the entire original group and among those who had made either choice there also were consistent differences in the rhythm of gaining adulthood between the sexes: girls more often than boys actually left the childhood home at an early date and formed new families. 
The observations made in the longitudinal study on the beginnings of adulthood, the great differences in the rhythm of becoming an adult, and the differences between the sexes can be examined by comparing them to population statistics on how the entire population age group of young people varied in relation to place of residence and marital status at the time of The Upper Secondary School Study 1964-71 (in this case in 1969).

In regard to the formation of marital unions the process of becoming an adult had similar patterns in the entire population age groups but took place even earlier than in the group that left after lower secondary school: while only a few 15-year-old girls were married, already almost every tenth 18-year-old girl was married, more than one out of four 20-year-old girls and almost every other 22-year-old girl was married. At the age of 20 almost every tenth boy was married, at 22 well over every fourth boy, and at 24 every other boy. In the total age group of 21- and 22-year-olds used for comparison $22 \%$ of the boys and about $43 \%$ of the girls were already married, in other words definitely a larger number than in the entire original lower secondary school group that has been followed here.

Thus the same patterns in gaining social adulthood that showed up in the longitudinal study were repeated in the entire population: an early beginning (even earlier), the difference in the rhythms of boys and girls within the same age group and the fact that the schedule of girls is two years ahead of the boys.

Although signs of becoming an adult considered where have been social changes, they must be connected with individual rhythm patterns found in physiological growth and maturation: puberty can normally begin any time during a period of six years, puberty in girls begins on the average two years before it does in boys and puberty among youth as a whole has in a period of three decades gradually begun about one year earlier in all the industrialized countries (e.g. Tanner 1960). Changes brought on by physiological maturation bring about changes in the behavior of the individual himself and in the behavior of the social environment toward him, which probably explains in part the different patterns in the rhythm of gaining social adulthood.

\section{Education policy: the challenge of flexibility made necessary by population policy and demands for equality}

What conclusions should be made in the sphere of education policy in regard to the great individual differences found in the rhythm of socially and fysiologically gaining adulthood? A significant observation seems to be that efforts to increase the speed at which one becomes an adult and dissatisfaction in the role of pupil which is felt to be the opposite of an adult's role more clearly than any other factors caused many young people to give up upper secondary 
$\mathrm{Table}$ 4. Population events in 1969: age distributions of men and women who entered their first marriage in 1969 and age distributions of the fathers of legitimate children and mothers of all children born in 1969 (Calculated and combined from tables 8, 9, 25 and 33 of SVT VI A: 131 Population changes in 1969, Helsinki 1972).

\begin{tabular}{|c|c|c|c|c|}
\hline \multirow[b]{2}{*}{$\begin{array}{l}\text { Age groups } \\
\text { years }\end{array}$} & \multicolumn{2}{|c|}{$\begin{array}{l}\text { Age at first marriage } \\
\text { in } 1969\end{array}$} & \multicolumn{2}{|c|}{$\begin{array}{l}\text { Age of parents of live-born } \\
\text { children in } 1969\end{array}$} \\
\hline & $\begin{array}{l}\text { Men } \\
\%\end{array}$ & $\begin{array}{c}\text { Women } \\
\%\end{array}$ & $\begin{array}{c}\text { Fathers } \\
\text { (of legitimate } \\
\text { children) } \\
0 \%\end{array}$ & $\begin{array}{l}\text { Mothers } \\
\text { (of all } \\
\text { children) } \\
\% \%\end{array}$ \\
\hline 14 & - & - & & (0) \\
\hline 15 & - & (0) $\}_{1}$ & & (0) \\
\hline 16 & (0) , & $(0)\}^{1}$ & & (0) \\
\hline 17 & (0) $\}^{1}$ & 5 & & 2 \\
\hline 18 & 2 & 8 & & 3 \\
\hline 19 & 5 & 11 & & 5 \\
\hline 20 & 8 & 13 & & 7 \\
\hline 21 & 13 & 14 & & 8 \\
\hline 22 & 14 & 13 & & 9 \\
\hline 23 & 16 & 11 & & 9 \\
\hline 24 & 9 & 6 & & 6 \\
\hline $14-19$ & 8 & 25 & 3 & 10 \\
\hline $20-24$ & 60 & 57 & 30 & 39 \\
\hline $25-29$ & 22 & 12 & 30 & 26 \\
\hline $30-34$ & 6 & 3 & 19 & 15 \\
\hline over 35 & 4 & 3 & 18 & 10 \\
\hline Total & 100 & 100 & 100 & 100 \\
\hline $\mathrm{n}$ & 36325 & 37853 & 63643 & 67450 \\
\hline
\end{tabular}

school, which would mean three or four more years as a pupil. This way social adulthood was achieved more rapidly in practice.

The principle of equality means that everyone have the same actual opportunities to learn the basic facts and abilities needed in this society. On the other hand this does not necessarily mean that this learning should take place in one long continuous period, at a certain age and as full-time schooling.

There have been increasing voices around the world bringing attention to the evergrowing discontent among pupils, especially older ones, with their role. For example, Coleman, the sociologist, (1972) who has studied inequality in American education has demanded that young people be allowed to become adults, to participate in social adulthood by being allowed early enough to also participate actively in work, economic production, to be an actual part of society. This idea has been included in the basic concept of polytechnic education. 
It must be asked whether actual equality in learning would not increase, if starting at a certain age there would be officially recognized economic and practical opportunities, for example, to alternate periods of work and study or to combine them part-time without, however, allowing the total burden to become unbearable. This way work and study could be brought into interaction. The idea of continual adult education would be a natural outcome.

Society does not generally tie the responsibilities of adult citizens exclusively to a certain chronological age. Even the stiff military service system covers a ten-year age span with the aid of voluntary enlistment and the possibility of postponement. It has also been suggested that the pension system, which is tied to different ages, be made more flexible, for example by offering a choice concerning when the pension will start and an opportunity to combine part-time work and a partial pension. (compare with the recommendations of the Swedish Metal Worker' Union 1973).

There is good reason to expect that the flexibility desired at the end of the period of active work in life also be arranged at the beginning of this period, especially when an emphasis on participation and experience in work in admitting people to training and education could level out social differences now apparent in education.

There is reason, especially in regard to population policy, to examine table 4 to find out whom children are born to nowadays and to crystallize some demands for this phase in gaining adulthood, demands caused in part by the principle of equality:

- parents should be happy to have their children;

- a child chould be ensured of sufficient safe and loving care not only at birth but for at least twenty years ahead;

- both the mother and the father of the child should be ensured of a position equal to others in working life for these twenty years and/or after them.

Table 4 shows that children are being born to increasingly younger people: in 1969 every tenth child was born to a mother under 20, every fourth was born to a mother under 22 and every other child to a mother under 24. Every third child was born to a father 24 years old or younger.

If the only educational system insuring occupational competence covers these years and lacks necessary flexibility, it is possible that some of these children will not be born (births put off till a considerably later age are beginning to be rare, as can be seen in table 4) or else their mother (or both parents) will come under unbearable pressure and/or because of a lack of education she (or both) will be in a considerably worse position in the labor force than are others, which will be reflected in the growth environment of the child in many ways.

It is especially the opportunities women have to give birth and to care for their children in positive and healthy circumstances which depend mainly on the flexible and equal opportunities offered them by education and labor policy. If these are lacking the children of an industrialized society will either not be born or will not be cared for. 
Up till now there has been little discussion on the interaction prevailing between population policy and education policy. Children born to school pupils, even to those in vocational schools or to students, have mainly been considered accidents, exceptions to the rule or a matter which concerns only the parents. With education increasing and taking longer it is absolutely necessary to take into consideration as an essential part of education policy the marriages that are formed and the children that are born, taken care of and brought up while the parents are being educated, unless we want to make the situation too difficult for children and also for women.

\section{Bibliography}

Aalto, Ritva ja Minkkinen, Sirkka (toim.): Nuoret tänään. Otava. 1971.

Coleman, James S.: How do the young become adults? Review of Educ. Research 1972, $431-439$.

Rantalaiho, Kari: Nuoriso ja yhteiskunta. Otava 1968.

Sysiharju, Anna-Liisa: Keskikoulusta eteenpäin 1960-luvun Suomessa. Lukiotutkimus 1964-71: koulutusurat. Kasvatustieteiden tutkimuslaitos, Jyväskylä, 123-127/1972.

Tanner, J. M.: Education and physical growth. Implications of the study of children's growth for educational theory and practice. University of London Press, 1970. 